\title{
Implementasi Metode C.45 dalam Menganalisa Tingkat Kecemasan Mahasiswa Menyusun Tugas Akhir
}

\author{
Desyanti \\ Program Studi Teknik Informatika, Sekolah Tinggi Teknologi Dumai \\ Jl. Utama Karya Bukit Batrem II \\ Email: desyanti734@gmail.com
}

\begin{abstract}
ABSTRAK
Tugas Akhir adalah mata kuliah wajib yang harus diambil oleh mahasiwa mahasiswi sebagai salah satu syarat untuk memperoleh gelar Ahli Madya (Amd) di AMIK Mitra Gama. Permasalahan yang terjadi adalah mahasiswa sering kali mengalami kesulitan - kesulitan dalam menyelesaikan tugas akhir tersebut, antara lain pemilihan judul yang relatif lama karena membutuhkan banyak pertimbangan dalam penentuan judul, pemilihan metode penelitian yang sesuai dengan judul yang akan diajukan serta proses mempertahankan gagasan di depan dosen pembimbing yang tidak mudah sering kali dirasakan sebagai beban yang berat. Akibat kesulitankesulitan tersebut berkembang menjadi sikap yang negatif yang menimbulkan suatu kecemasan dan hilangnya motivasi untuk menyelesaikan Tugas Akhir. Oleh karena itu, diperlukan sebuah analisa yang dibutuhkan oleh kampus untuk dapat membantu mahasiswa dalam menyelesaikan tugas akhirnya sesuai dengan lama masa studinya. Oleh karena itu untuk mengatasi masalah tersebut diterapkan data mining dengan metode $\mathrm{C} 4.5$ untuk mengetahui tingkat kecemasan mahasiswa dalam menyusun tugas akhir.
\end{abstract}

Kata Kunci: Tugas Akhir, Kecemasan, Data Mining, C45

\begin{abstract}
The Final Projects a compulsory course that must be taken by students as one of the requirements to obtain an Associate Expert degree (AMD) at AMIK Mitra Gama. The problem that occurs is that students often experience difficulties in completing the final project, including the selection of a relatively long title because it requires a lot of consideration in determining the title, selecting research methods that are in accordance with the title to be submitted and the process of defending ideas in front of the supervisor. What is not easy is often felt as a heavy burden. As a result of these difficulties develop into a negative attitude that causes anxiety and loss of motivation to complete the Final Project. Therefore, an analysis is needed that is needed by the campus to be able to assist students in completing their final assignments according to the length of their study period. Therefore, to overcome this problem, data mining is applied with the C4.5 method to determine the level of student anxiety in compiling the final project.
\end{abstract}

Keywords: Final Project, Anxiety, Data Mining, C45 


\section{Pendahuluan}

Tugas Akhir merupakan karya tulis ilmiah sebagai salah satu hasil proses pengembangan intelektual mahasiswa secara mandiri dan sesuai ketentuan yang telah ditetapkan di bawah bimbingan dosen. Keharusan menyusun tugas akhir dimaksudkan agar mahasiswa mampu menerapkan ilmu dan kemampuan sesuai dengan disiplin ilmu yang dimiliki kedalam kenyataan yang dihadapi.

Akademi Manajemen Informatika (AMIK) Mitra Gama merupakan salah satu perguruan tinggi yang ada di kota Duri Propinsi Riau yang memiliki 2 program studi yaitu Manajemen Informatika dan Teknik Komputer. Penulisan Tugas Akhir merupakan salah satu syarat untuk menyelesaikan pendidikan pada program D3 yang memiliki bobot 6 sks ( satuan kredit semester). Dalam penyusunan Tugas Akhir mahasiswa banyak mengalami kesulitan. Kesulitan - kesulitan yang dialami oleh mahasiswa saat menyusun Tugas Akhir antara lain pemilihan judul yang relatif lama karena membutuhkan banyak pertimbangan dalam penentuan judul, pemilihan metode penelitian yang sesuai dengan judul yang akan diajukan serta proses mempertahankan gagasan di depan dosen pembimbing yang tidak mudah sering kali dirasakan sebagai beban yang berat. Akibat kesulitan - kesulitan tersebut berkembang menjadi sikap yang negatif yang menimbulkan suatu kecemasan dan hilangnya motivasi untuk menyelesaikan Tugas Akhir. Pada Penelitian sebelumnya yang berjudul "Penerapan Algoritma C4.5 untuk penentuan jurusan mahasiswa (Swastina, 2013) membahas tentang implementasi data mining pada proses penentuan jurusan mahasiswa dengan menggunakan data mahasiswa baru STMIK Indonesia Banjarmasin tahun 2008 - 2009. Hasil penelitian tersebut menunjukkan bahwa proses pembentukan pohon algoritma C4.5 akurat diterapkan untuk penentuan kesesuaian jurusan mahasiswa dengan tingkat keakuratan 93,31 $\%$ dan akurasi rekomendasi jurusan sebesar $82,64 \%$. Kemudian dalam penelitian Implementasi data mining algoritma C4.5 untuk memprediksi jumlah peserta matakuliah pilihan (Alfiansyah, 2018), jurnal ini membahas tentang membangun aplikasi yang dapat membantu pihak akademik memprediksi jumlah peserta yang akan memilih matakuliah dengan Algoritma C4.5 dengan database server MySQL.

Kemudian penelitian (Nasrullah, 2018), (Desyanti, 2018), dan (Sari, 2018) menunjukan bahwa algoritma C4.5 mampu untuk mengatasi permasalahan yang dihadapi serta menghasilkan informasi yang dibutuhkan oleh penulis. Data mining adalah proses yang mempekerjakan satu atau lebih teknik pembelajaran (machine learning) untuk menganalisis dan mengekstraksi pengetahuan (knowledge) secara otomatis (Hermawati, 2013)

Menurut Pramudiono, Data mining adalah serangkaian proses untuk menggali nilai tambah dari suatu kumpulan data berupa mengetahuan yang selama ini tidak diketahui secara manual (Kusrini, 2009), dalam Jurnal (Machsan, 2012) Hubungan antara penerimaan diri dengan kecemasan menghadapi dunia kerja pada tunadaksa di UPT Rehabilatasi sosial cacat tubuh menjelaskan bahwa kecemasan adalah suatu keadaan emosional yang mempunyai ciri - ciri seperti keterangsangan fisioligis, perasaan tegang yang tidak menenangkandan perasaan aprehensif atau keadaan khawatir yang mengeluhkan bahwa suatu yang buruk akan terjadi.

Kemudian dalam jurnal karya (Hudianingsih, 2012) mengartikan kecemasan sebagai respon terhadap situasi tertentu yang mengancam yang sumbernya tidak diketahui dan internal, kecemasan adalah munculnya perasaan takut dan berhatihati atau kewaspadaan yang tidak jelas dan tidak menyenangkan. 
Kecemasan diidentifikasi menjadi 4 tingkat (level) yaitu; ringan, sedang, berat, dan panik (Purnomo, 2009)

1. Kecemasan Ringan

Kecemasan ringan berhubungan dengan kehidupan sehari-hari dan menyebabkan seseorang menjadi waspada dan meningkatkan lapang persepsinya. Individu melihat, mendengar, dan memegang secara lebih dibanding sebelumnya. Kecemasan jenis ini dapat memotivasi belajar dan menghasilkan perkembangan dan kreativitas.

2. Kecemasan Sedang

Kecemasan sedang memungkinkan seseorang hanya berfokus pada persoalan yang sedang, melibatkan penyempitan dari lapangan persepsi sehingga individu kurang melihat, mendengar dan menggenggam. Individu menahan beberapa area terpilih tetapi dapat menyelesaikan jika diarahkan.

3. Kecemasan Berat

Kecemasan berat ditandai oleh penurunan lapang persepsi. Individu cenderung berfokus pada sesuatu yang khusus dan detail dan tidak berfikir tentang hal-hal lain. Semua tingkah laku pada pengurangan kecemasan, dan memerlukan banyak bimbingan untuk berfokus pada area yang lain.

Kecemasan dapat dialami oleh semua orang dalam menghadapi beberapa persoalan seperti dalam menghadapi ujian berbasis komputer (Annisa, 2018). Tingkat kecemasan dapat berubah menjadi depresi, sama dengan tingkat kecemasan tingkat depresi juga dapat diukur dengan alat Tes Beck Depression Inventory yang dihubungkan dengan data statistik kecemasan sehingga terdapat perbedaan derajat kecemasan dan depresi (Subarjdo, 2018)

Dalam jurnal karya (Budiaji, 2013) Skala Likert merupakan skala pengukuran yang dikembangkan oleh Likert pada tahun 1932. Skala likert mempunyai empat atau lebih butir-butir pertanyaan yang dikombinasikan sehingga membentuk sebuah skor/nilai yang mempresentasikan sifat individu, misalkan pengetahuan, sikap dan prilaku. Dalam proses analisis data, komposit skor, biasanya jumlah atau rataan, dari semua butir pertanyaan dapat digunakan. Penggunaan jumlah dari semua butir pertanyaan valid karena setiap butir pertanyaan adalah indikator dari variabel yang direpresentasikannya.

Prinsip Pokok Skala Likert adalah menentukan lokasi kedudukan seseorang dalam suatu kontinum sikap terhadap objek sikap, mulai dari yang sangat negatif sampai dengan sangat positif . Dengan Skala Likert maka variabel yang akan diukur dijabarkan menjadi indikator variabel. Kemudian indikator tersebut dijadikan sebagai titik tolak menyusun butir - butir instrument yang berupa pertanyaan atau penyataan yang perlu dijawab oleh responden. Setiap Jawaban dihubungkan dengan bentuk pernyataan atau dukungan sikap yang diungkapkan dengan kata - kata (Widoyoko, 2014).

Metode pohon keputusan mengubah fakta yang sangat besar menjadi pohon keputusan yang merepresentasikan aturan. Algoritma C4.5 merupakan algoritma yang digunakan untuk membentuk pohon keputusan. Pohon keputusan merupakan metode klasifikasi dan prediksi yang sangat kuat dan terkenal dipahami dengan bahasa alami. Dan mereka juga dapat diekspresikan dalam bentuk bahasa basis data seperti Structured Query Language untuk mencari record pada kategori tertentu.

Secara umum algoritma C4.5 untuk membangun pohon keputusan adalah sebagai berikut :

Pilih atribut sebagai akar.

a. Buat cabang untuk tiap-tiap nilai.

b. Bagi kasus dalam cabang. 
c. Ulangi proses untuk setiap cabang sampai semua kasus pada cabang memiliki kelas yang sama.

Dalam algortima C4.5 digunakan gain untuk memilih atribut yang akan digunakan untuk pemisahan objek. Sebelum mendapatkan nilai Gain adalah mencari nilai Entropy. Entropy digunakan untuk menentukan seberapa informatif sebuah masukan atribut untuk menghasilkan keluaran atribut.

Entropy merupakan distribusi probabilitas dalam teori informasi dan diadopsi ke dalam algoritma C4.5 untuk mengukur tingkat homogenitas distribusi kelas dari sebuah himpunan data (data set). Sebagai ilustrasi, semakin tinggi tingkat entropi dari sebuah data set maka semakin homogen distribusi kelas pada data set tersebut [15].

Sementara itu, perhitungan nilai entropi dapat dilihat pada persamaan berikut:

$$
\text { Entropy }(S)=\sum_{i=1}^{n}-p i * \log _{2} p i
$$

Keterangan:

S : himpunan kasus

A : fitur

$\mathrm{n} \quad$ : jumlah partisi S

$\mathrm{p}_{\mathrm{i}} \quad$ : proporsi dari $\mathrm{S}_{\mathrm{i}}$ terhadap $\mathrm{S}$

Setelah membagi data set berdasarkan sebuah atribut kedalam subset yang lebih kecil, entropi dari data tersebut akan berubah. Perubahan entropi ini dapat digunakan untuk menentukan bagus tidaknya pembagian data yang telah dilakukan. Perubahan entropi ini disebut dengan gain dalam algoritma C4.5. Gain ini diukur dengan menghitung selisih antara entropi data set sebelum dan sesudah pembagian (splitting) dilakukan. Pembagian yang terbaik akan menghasilkan entropi subset yang paling kecil, dengan demikian berdampak pada gain yang terbesar [14]. Untuk memilih atribut sebagai akar, didasarkan pada nilai gain tertinggi dari atribut-atribut yang ada.

Untuk menghitung Gain digunakan rumus

$$
\cdot \operatorname{Gain}(S, A)=\operatorname{Entropy}(S)-\sum_{i=1}^{n} \frac{\left\|S_{i}\right\|}{\|S\|} * \text { Entropy }(S i)
$$

Keterangan:

$$
\begin{array}{ll}
\mathrm{S} & \text { : himpunan kasus } \\
\mathrm{A} & \text { : atribut } \\
\mathrm{n} & \text { : jumlah partisi atribut } \mathrm{A} \\
|\mathrm{Si}| & \text { : jumlah kasus pada partisi ke-i } \\
|\mathrm{S}| & \text { : jumlah kasus dalam } \mathrm{S}
\end{array}
$$

\section{Metode Penelitian}

Penelitian ini menggunakan Metode C.45 dalam menganalisa tingkat kecemasan mahasiswa dalam penyusunan tugas akhir. Metode pengembangan sistem yang digunakan adalah model SDLC (Software Development Life Cycle)air terjun atau waterfall. Model air terjun menyediakan pendekatan alur hidup perangkat lunak secara sekuensial atau terurut di mulai dari analisis, desain, pengkodean, dan pengujian [16].Tahapan-tahapan dari waterfall adalah :

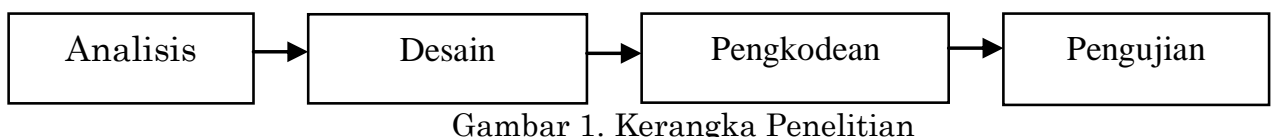

Gambar 1. Kerangka Penelitian 
Unitek : Jurnal Universal Teknologi

Vol. 14 No.1 Januari-Juni 2021

e-ISSN : 2580-2582, p-ISSN: 2089-3957

\section{Hasil dan Pembahasan}

Penelitian ini dilakukan dengan menyebarkan quisioner kepada mahasiswa mahasiswi AMIK Mitra Gama Duri yang sedang melakukan tugas akhir. Data yang diperoleh dari hasil penyebaran quisioner sebanyak 103 mahasiswa. Dari data tersebut selanjutnya penulis melakukan seleksi pada data quisioner tingkat kecemasan mahasiswa dalam menghadapi tugas akhir. Setelah diseleksi data diubah menjadi bentuk yang sesuai dengan kebutuhan. Adapun data yang sudah ditransformasi dapat dilihat pada tabel 1 .

Tabel 1. Data Kecemasan Mahasiswa Yang Sedang Menyusun Tugas Akhir

\begin{tabular}{ccccccc} 
No & Nim & $\begin{array}{c}\text { Pemahaman } \\
\text { Materi } \\
\text { Penelitian }\end{array}$ & $\begin{array}{c}\text { Dosen } \\
\text { Pmbmbng }\end{array}$ & $\begin{array}{c}\text { Birokrasi } \\
\text { Kampus }\end{array}$ & $\begin{array}{c}\text { Kuliah } \\
\text { sambil } \\
\text { Bekerja }\end{array}$ & Total \\
\hline 1 & 094 & 13 & 11 & 7 & 8 & 39 \\
2 & 032 & 15 & 12 & 9 & 9 & 45 \\
3 & 115 & 12 & 12 & 7 & 6 & 37 \\
4 & 113 & 13 & 12 & 8 & 6 & 39 \\
5 & 139 & 11 & 13 & 7 & 7 & 38 \\
6 & 101 & 16 & 12 & 9 & 9 & 46 \\
7 & 092 & 11 & 11 & 7 & 7 & 36 \\
8 & 086 & 15 & 10 & 8 & 9 & 42 \\
9 & 121 & 13 & 12 & 8 & 7 & 40 \\
10 & 131 & 15 & 11 & 9 & 7 & 42 \\
11 & 102 & 20 & 13 & 9 & 9 & 51 \\
12 & 040 & 15 & 11 & 8 & 8 & 42 \\
\hline
\end{tabular}

Penyelesaian:

a. Hitung Jumlah Kasus

b. Hitung Jumlah Keputusan "Kecemasan Sedang (KS)"

c. Hitung Jumlah Keputusan "Kecemasan Ringan (KR)"

d. Hitung :

- Entropy (Total)

- Entropy (Pemahaman Terhadap Materi Penelitian)

- $\quad$ Entropy (Dosen Pembimbing)

- Entropy (Birokrasi Kampus)

- Entropy (Kuliah Sambil Bekerja)

e. Hitung :

- Gain (Total, Pemahaman terhadap Materi Penelitian)

- Gain (Total, Dosen Pembimbing)

- Gain (Total, Birokrasi Kampus)

- Gain (Total, Kuliah Sambil Bekerja) 
Unitek : Jurnal Universal Teknologi

Vol. 14 No.1 Januari-Juni 2021

e-ISSN : 2580-2582, p-ISSN: 2089-3957

Tabel 2. Perhitungan Node 1

\begin{tabular}{|c|c|c|c|c|c|c|c|}
\hline $\mathrm{Nd}$ & & & $\begin{array}{c}\text { Jlh } \\
\text { Kasus } \\
\text { (S) }\end{array}$ & $\mathrm{KS}$ & $\mathrm{KR}$ & Entp & Gain \\
\hline \multirow[t]{20}{*}{1} & Total & & 103 & 45 & 58 & 0.988 & \\
\hline & Pemahaman & & & & & & \\
\hline & Materi & & & & & & 0.229 \\
\hline & Penelitian & & & & & & \\
\hline & & $\begin{array}{l}\text { Krg } \\
\text { phm }\end{array}$ & 70 & 43 & 27 & 0.961 & \\
\hline & & Paham & 33 & 2 & 31 & 0.329 & \\
\hline & $\begin{array}{l}\text { Dosen } \\
\text { Pembimbing }\end{array}$ & & & & & & 0.047 \\
\hline & & Tdk & & & & & \\
\hline & & Mghbt & 99 & 41 & 58 & 0.978 & \\
\hline & & Mghbt & 4 & 4 & 0 & 0 & \\
\hline & $\begin{array}{l}\text { Birokrasi } \\
\text { Kampus }\end{array}$ & & & & & & 0.0002 \\
\hline & & Tdk & & & & 0988 & \\
\hline & & Mghbt & 101 & 44 & 57 & 0.988 & \\
\hline & & Mghbt & 2 & 1 & 1 & 1 & \\
\hline & Kuliah & & & & & & \\
\hline & Sambil & & & & & & 0.047 \\
\hline & Bekerja & & & & & & \\
\hline & & Tdk & & & & 0.978 & \\
\hline & & Mghbt & 99 & 41 & 58 & & \\
\hline & & Mnggu & 4 & 4 & 0 & 0 & \\
\hline
\end{tabular}

Dari hasil tersebut dapat digambarkan pohon keputusan sementara tampak seperti gambar. 2

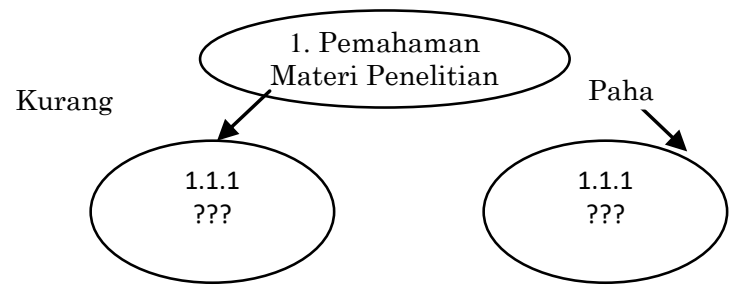

Gambar. 2 Pohon Keputusan Hasil Perhitungan Node 1

Selanjutnya dilakukan perhitungan node 1.1 yang dapat dilihat pada tabel 3 .

Tabel 3. Perhitungan Node 1.1

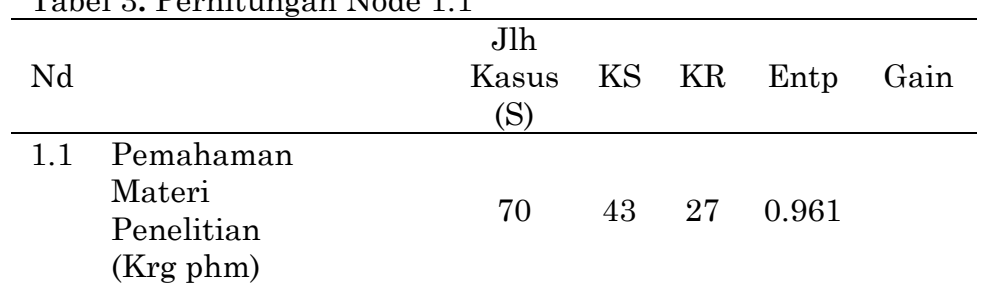


Unitek : Jurnal Universal Teknologi

Vol. 14 No.1 Januari-Juni 2021

e-ISSN : 2580-2582, p-ISSN: 2089-3957

\begin{tabular}{llccccc}
$\begin{array}{l}\text { Dosen } \\
\text { Pembimbing }\end{array}$ & & & & & & 0.020 \\
& Tdk & & & & & \\
& Mghbt & 68 & 41 & 27 & 0.969 & \\
& Mghbt & 2 & 2 & 0 & 0 & \\
Birokrasi & & & & & & 0.010 \\
Kampus & Tdk & 69 & 42 & 27 & 0.965 & \\
& Mghbt & & & & \\
& Mghbt & 1 & 1 & 0 & 0 & \\
Kuliah & & & & & & 0.041 \\
Sambil & & & & & & \\
Bekerja & Tdk & & & & & \\
& Mghbt & 66 & 39 & 27 & 0.976 & \\
& Mnggu & 4 & 4 & 0 & 0 & \\
\hline
\end{tabular}

Dari hasil tersebut dapat digambarkan pohon keputusan sementara tampak seperti gambar 3.

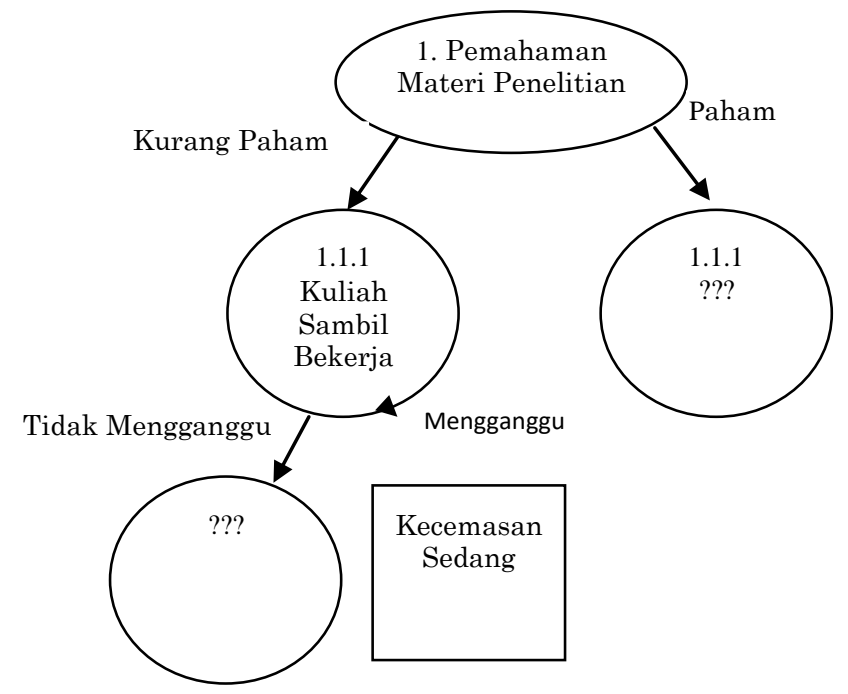

Gambar 3. Pohon Keputusan Hasil Perhitungan Node 1.1

Setelah didapat pohon kepurtusan pada node 1.1 dilakukan perhitungan node 1.2 yang dapat dilihat pada tabel 4 .

Tabel 4. Perhitungan Node 1.2

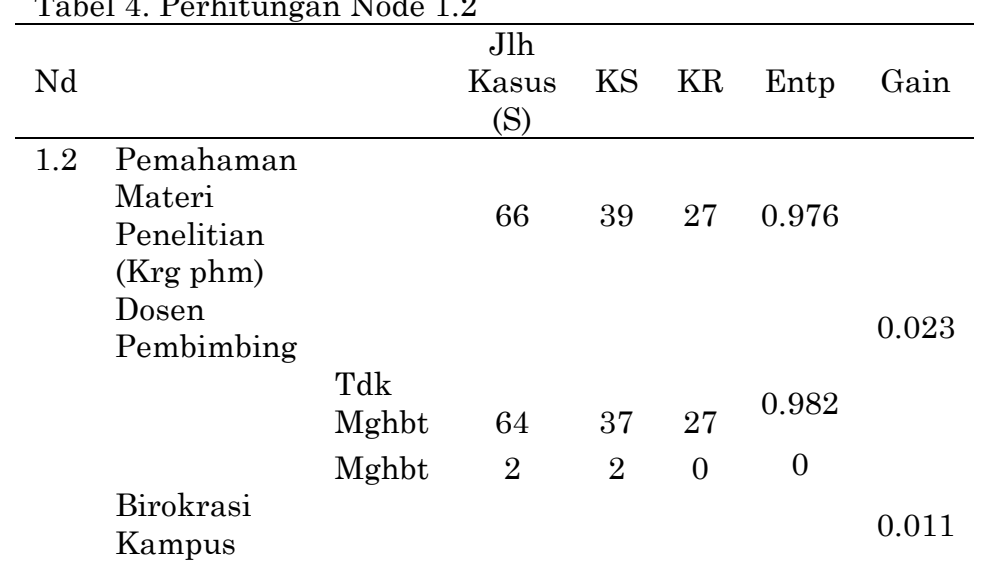


Unitek : Jurnal Universal Teknologi

Vol. 14 No.1 Januari-Juni 2021

e-ISSN : 2580-2582, p-ISSN: 2089-3957

Tdk

$\begin{array}{lllll}\text { Mghbt } \quad 65 & 38 & 27 & 0.979\end{array}$

$\begin{array}{lllll}\text { Mghbt } & 1 & 1 & 0 & 0\end{array}$

Dari hasil tersebut dapat digambarkan pohon keputusan sementara tampak seperti Gambar 5.

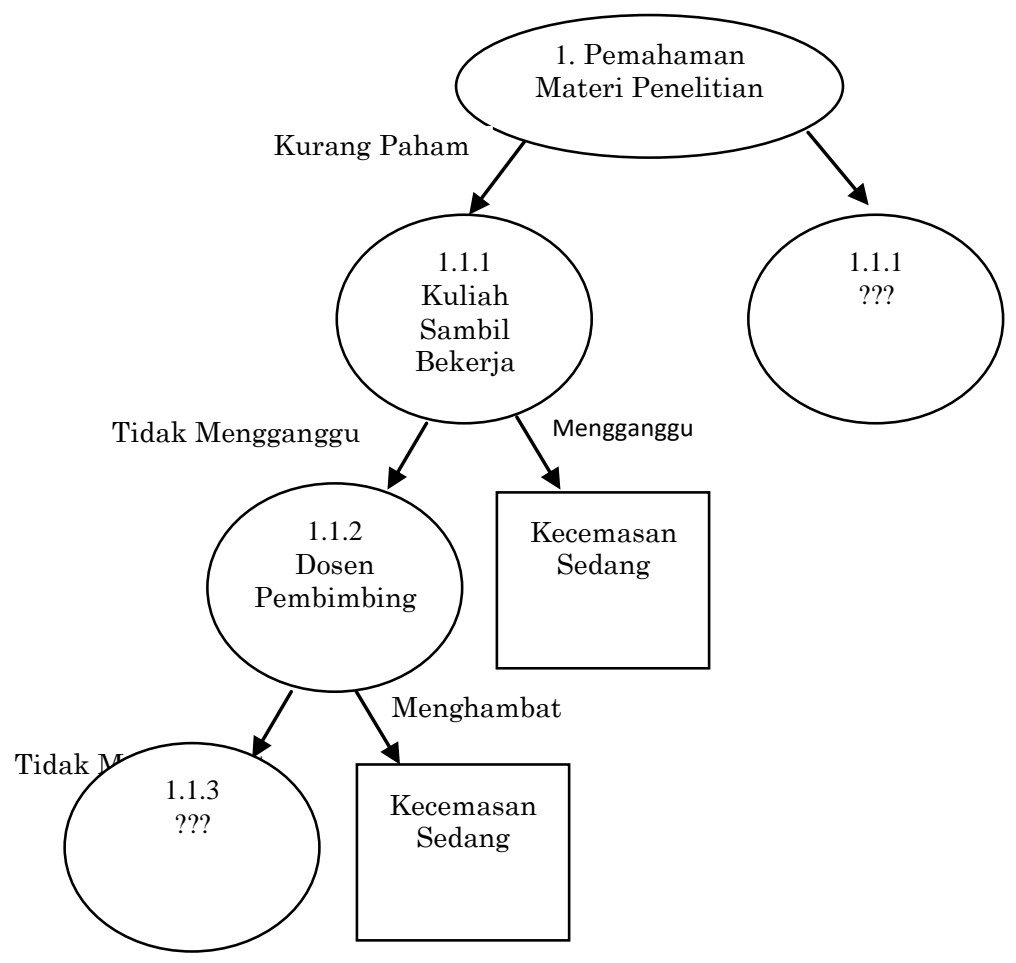

Gambar 5. Pohon Keputusan Hasil Perhitungan Node 1.2

Kemudian dilakukan perhitungan node 1.3 yang dapat dilihat pada tabel 5 .

Tabel 5. Perhitungan Node 1.3

\begin{tabular}{|c|c|c|c|c|c|c|c|}
\hline $\mathrm{Nd}$ & 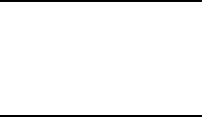 & & $\begin{array}{c}\text { Jlh } \\
\text { Kasus } \\
\text { (S) }\end{array}$ & $\mathrm{KS}$ & $\mathrm{KR}$ & Entp & Gain \\
\hline 1.3 & $\begin{array}{l}\text { Pemahaman } \\
\text { Materi } \\
\text { Penelitian } \\
\text { (Krg Phm) } \\
\text { kuliah } \\
\text { sambil kerja } \\
\text { (Tdk } \\
\text { mnggu) \& } \\
\text { Dosen } \\
\text { Pembimbing } \\
\text { (Tdk Mhbt) } \\
\text { Birokrasi } \\
\text { Kampus }\end{array}$ & $\begin{array}{c}\text { Tdk } \\
\text { Mghbt } \\
\text { Mghbt }\end{array}$ & $\begin{array}{c}64 \\
0\end{array}$ & $\begin{array}{c}37 \\
0\end{array}$ & $\begin{array}{c}27 \\
0\end{array}$ & $\begin{array}{c}0.982 \\
0\end{array}$ & 0.011 \\
\hline
\end{tabular}


Unitek : Jurnal Universal Teknologi

Vol. 14 No.1 Januari-Juni 2021

e-ISSN : 2580-2582, p-ISSN: 2089-3957

Dari hasil tersebut dapat digambarkan pohon keputusan sementara tampak seperti gambar 6 .

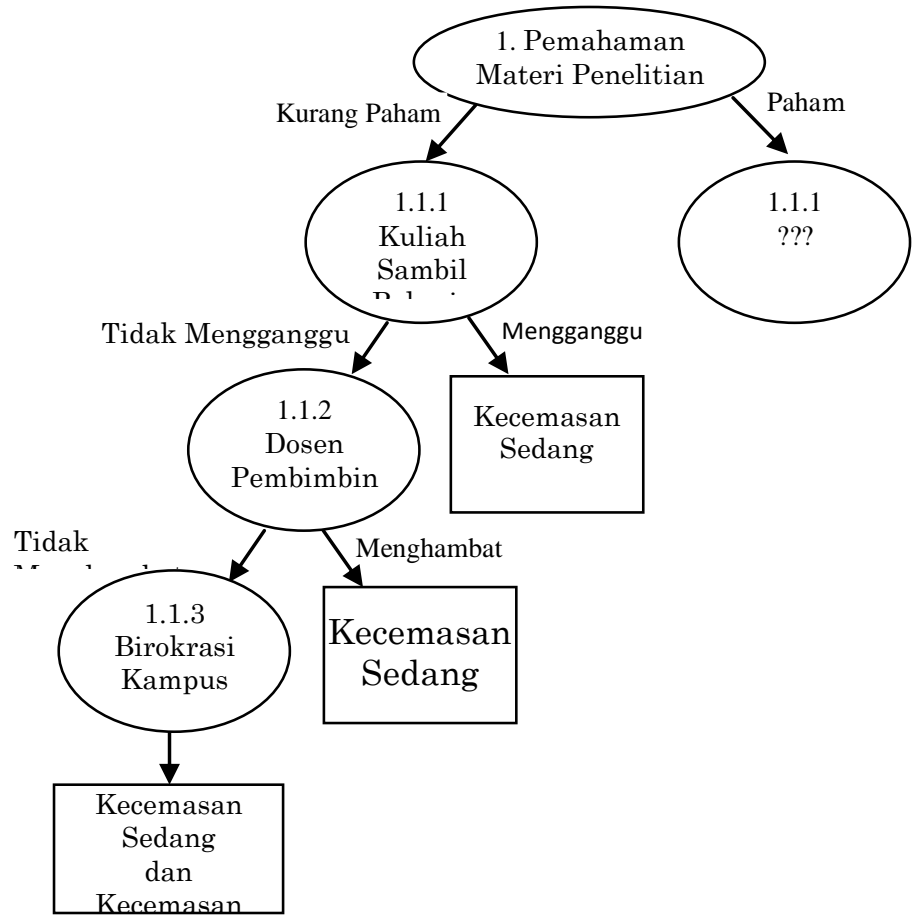

Gambar 6. Pohon Keputusan Hasil Perhitungan Node 1.3

Selanjutnya dilakukan perhitungan node 1.1 ( Paham )

Tabel 6. Perhitungan Node 1.1 ( Paham)

\begin{tabular}{|c|c|c|c|c|c|c|c|}
\hline $\mathrm{Nd}$ & & & $\begin{array}{c}\text { Jlh } \\
\text { Kasus } \\
(\mathrm{S}) \\
\end{array}$ & $\mathrm{KS}$ & $\mathrm{KR}$ & Entp & Gain \\
\hline \multirow[t]{10}{*}{1.1} & $\begin{array}{l}\text { Pmhmn } \\
\text { Terhadap } \\
\text { Materi } \\
\text { Penelitian } \\
\text { (Paham) }\end{array}$ & & 33 & 2 & 31 & 0.329 & \\
\hline & $\begin{array}{l}\text { Dosen } \\
\text { pmbmbng }\end{array}$ & & & & & & 0.329 \\
\hline & & $\begin{array}{l}\text { Tdk } \\
\text { Mghbt }\end{array}$ & 31 & 0 & 31 & 0 & \\
\hline & & Mghbt & 2 & 2 & 0 & 0 & \\
\hline & $\begin{array}{l}\text { Birokrasi } \\
\text { Kampus }\end{array}$ & & & & & & 0.002 \\
\hline & & $\begin{array}{l}\text { Tdk } \\
\text { Mghbt }\end{array}$ & 32 & 2 & 30 & 0.337 & \\
\hline & & Mghbt & 1 & 0 & 1 & 0 & \\
\hline & $\begin{array}{l}\text { Kuliah } \\
\text { Sambil } \\
\text { Bekerja }\end{array}$ & & & & & & 3.61 \\
\hline & & $\begin{array}{l}\text { Tdk } \\
\text { Mghbt }\end{array}$ & 33 & 2 & 31 & 0.329 & \\
\hline & & Mghbt & 0 & 0 & 0 & 0 & \\
\hline
\end{tabular}


Unitek : Jurnal Universal Teknologi

Vol. 14 No.1 Januari-Juni 2021

e-ISSN : 2580-2582, p-ISSN: 2089-3957

Dari hasil tersebut dapat digambarkan pohon keputusan sementara tampak seperti gambar 7 .

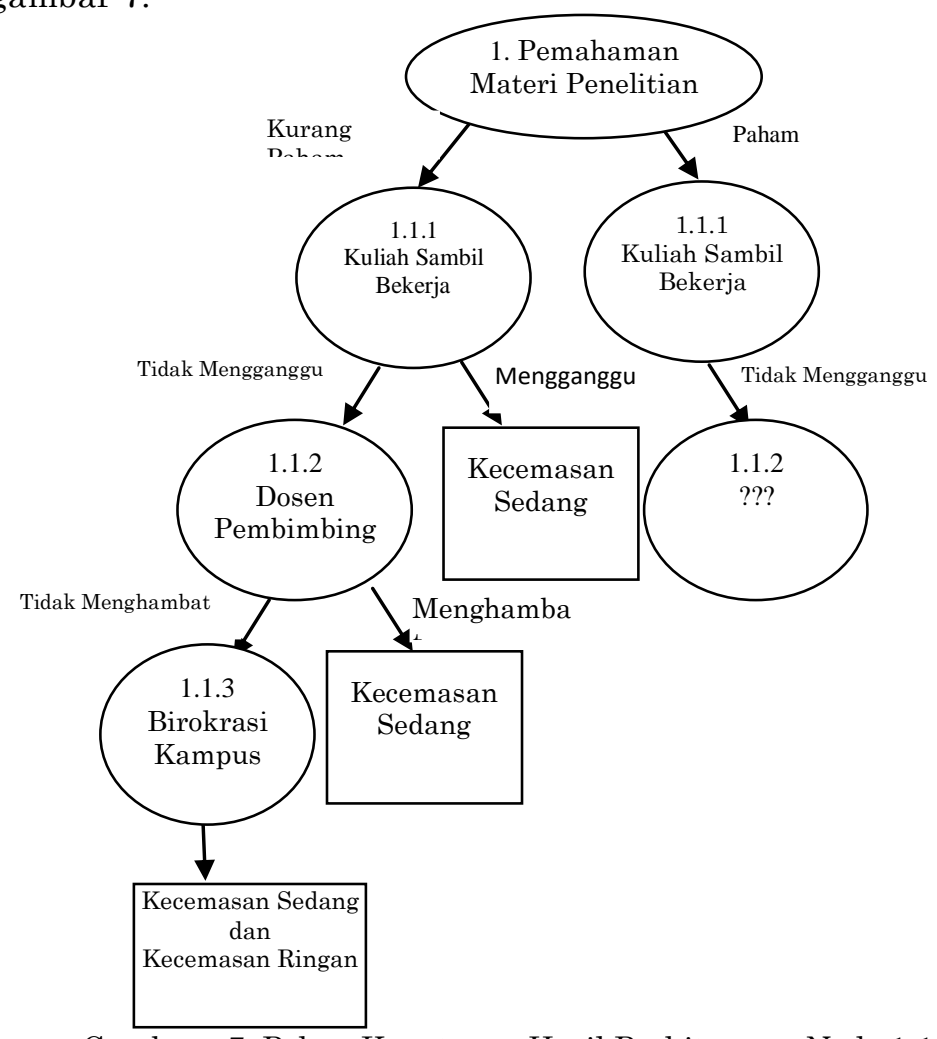

Gambar. 7 Pohon Keputusan Hasil Perhitungan Node 1.1 ( Paham)

Setalah itu dilakukan perhitungan node 1.2 ( Paham )

Tabel 7. Perhitungan Node 1.2 ( Paham)

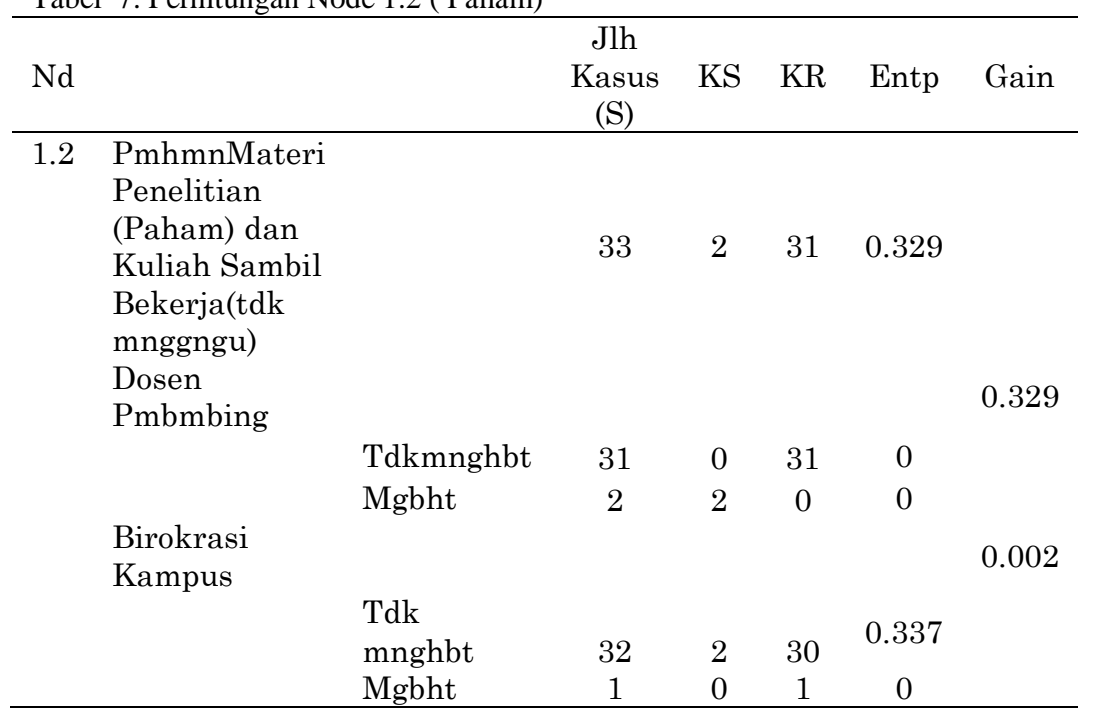


Unitek : Jurnal Universal Teknologi

Vol. 14 No.1 Januari-Juni 2021

e-ISSN : 2580-2582, p-ISSN: 2089-3957

Dari hasil tersebut dapat digambarkan pohon keputusan tampak seperti gambar 8 .

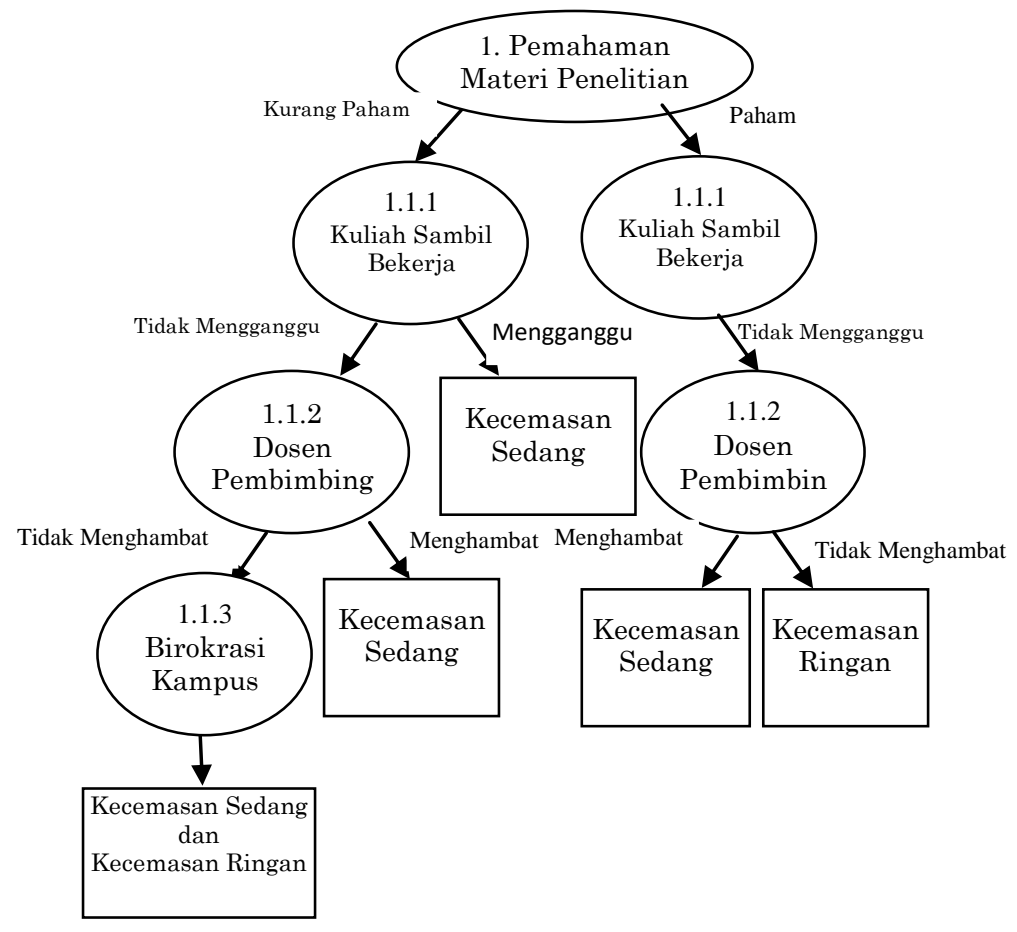

Gambar 8. Pohon Keputusan Hasil Perhitungan Node 1.2 (Paham)

Selanjutnya data mahasiswa yang sudah diolah dimasukan kedalam aplikasi Weka untuk dicari confusion matrixnya, hasil pencarian confusion matrix dapat dilihat pada gambar 9 .

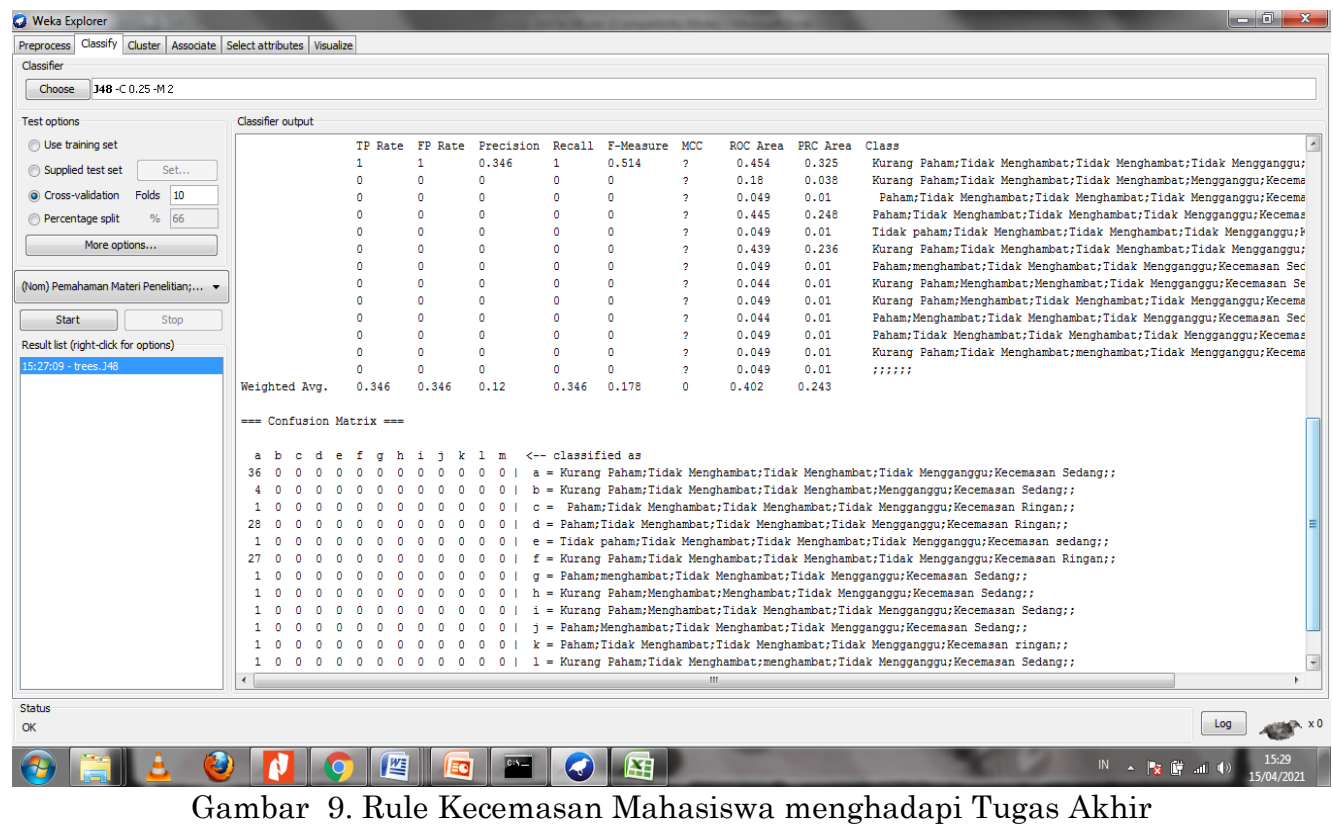




\section{Simpulan}

Berdasarkan hasil penelitian yang telah dilakukan, penggunakan metode C4.5 dalam menganalisa tingkat kecemasan mahasiswa menyusun tuhas akhir terdapat beberapa faktor penting yang harus diperhatikan yaitu pemahaman materi penelitian, dosen pembimbing dan birokrasi kampus. Dalam menyusun tugas akhir mahasiswa harus bisa memahami objek dan metode yang akan digunakan dalam penyelsaian tugas akhir, begitu juga dengan dosen pembimbing dan birokrasi kampus. Dosen pembimbing harus bisa berperan aktif dalam membimbing agar mahasiswa bimbingan merasa nyaman saat bimbingan

\section{Daftar Pustaka}

Alfiyansyah, Ilham., 2014. “ Implementasi Data Mining Algoritma C4.5 untuk memprediksi Jumlah Peserta Mata Kuliah Pilihan”, Yogyakarta: STMIK AMIKOM Yogyakarta.

Annisa Lisa Mutiara, Suryani, dkk, 2018 “ Tingkat Kecemasan Mahasiswa Keperawatan dalam Menghadapi UjianBerbasis Computer Based Test" MEDISAINS: Jurnal Ilmu - ilmu kesehatan, Vol 16, No 02 agustus 2018.

A,S Rosa, M.Shalahuddin. 2016"Rekayasa Perangkat Lunak"Informatika, Bandung. Budiaji,Weksi, USAT. 2013 " Skala Pengukuran dan Jumlah Respon Skala Likert", Jurnal Ilmu Pertanian dan Perikanan Desember 2013, ISSN: 2302-6308.

Desyanti, 2018. "Penerapan Data Mining C4.5 untuk Mengetahui Tingkat Kepuasan Konsumen di Hotel Grand Zuri Dumai", SATIN- Sain dan Teknologi Informasi, vol 4 no 02, Desember 2018.

Hermawati, Fajar Astuti, 2013. “ Data Mining”, Yogyakarta: Andi.

Hudiahningsi Tuti dan Wuyono Susanto, (2012) "Hubungan antara Kondisi Kesesaka dengan Kecemasan pada Manusia” ISSN 1907-8455 Vol 7 (2),81-87, 2012.

Kusrini dan Luthfi, E.T.2009. "Algoritma Data Mining”, Yogyakarta: Andi.

Machsan Denia M , Hartini Nurul. 2012. "Hubungan antara penerimaan diri dengan kecemasan menghadapi dunia kerja pada tunadaksa di UPT Rehabilasi sosial Cacat Tubuh Pasuruan”,.Jurnal Fsikologi Klinis dan Kesehatan Mental Vol.01 No.02, hal $79-85,2012$.

Nasrullah asmaul husnah, 2018 "Penerapan metode C4.5 untuk Klasifikasi Mahasiswa Berpotensi Drop Out" ILKOM Jurnal Ilmiah Volume 10 nomor 2 agustus 2018.

Purnomo, Muhammad Arif. IAIN Walisongo, 2012. Semarang. " Kecemasan Mahasiswa Semester Akhir Fakultas Dakwah IAIN Walisongo Semarang dan Upaya Solusinya “.

Raditya, Angga, 2015. "Implementasi Data Mining Classification untuk Mencari Pola Prediksi Hujan dengan menggunakan Algoritma C4.5”. Depok: Universitas Gunadarma.

Sari, Febrina, Saro, Davit 2018. “Implementasi Algoritma C4.5 Dalam Menentukan Lokasi Prioritas Penyuluhan Program Keluarga Berencana Di Kecamatan Dumai Timur", Jurnal Penelitian Pos dan Informatika Vol 8, No 1, 2018.

Subarjdo Ratna Yunita Setiyani, 2018. “ Pebedaan Tingkat Kecemasan Pada Mahasiswa Baru Difakultas Ilmu Kesehatan Dan Non Fakultas Ilmu Kesehatan Universitas Aisyiyah yogyakarta"Jurnal Psikologi Intergratif,Vol 6, No 1, 2018

Swastina, Liliana, 2013. "Penerapan Algoritma C4.5 Untuk Penentuan Jurusan Mahasiswa", Jurnal GEMA AKTUALITA, Vol. 2 No. 1, Juni 2013: 93-98. Banjarmasin: Program Studi Sistem Informasi STMIK Indonesia. 
Unitek : Jurnal Universal Teknologi

Vol. 14 No.1 Januari-Juni 2021

e-ISSN : 2580-2582, p-ISSN: 2089-3957

Widoyoko Eko Putro, 2014."Teknik Penyusunan Instrumen Penelitian", Pustaka Pelajar, Yogyakarta. 